\title{
Biodiversity Function and Resilience in Tropical Agroforestry Systems Including Shifting Cultivation
}

\author{
Lindsey Norgrove ${ }^{1} \cdot$ Jan Beck $^{1,2}$
}

Published online: 4 February 2016

(C) Springer International Publishing AG 2016

\begin{abstract}
Agroforestry systems potentially deliver win-win solutions to production and biodiversity conservation in the tropics, but they need to be adapted to farmers' needs. We reviewed the literature on functional roles of biodiversity and resilience in tropical agroforestry systems, and we evaluated the evidence base for the beneficial role of biodiversity on yield, and effects of farmer management practices. Most studies investigated the biodiversity of taxa assumed to have positive functions for farmers. Shaded commodities and shifting cultivation were the systems most frequently assessed. Half of studies investigated plants, while Hymenoptera and birds were other major groups. Many agroforests had lower diversity than forest, while less than half had higher diversity than agriculture. The effects of management within systems were rarely addressed, with shade level the most frequent factor. Papers on resilience, mainly from shifting cultivation systems, showed the positive influence of adjacent old-growth forest to biodiversity, and the negative effects of tillage. Better reporting of results for meta-analyses, and long-term experiments on key questions are needed to evaluate the potential of agroforestry more thoroughly.
\end{abstract}

This article is part of the Topical Collection on Ecological Function

Lindsey Norgrove

norgrove@airpost.net; lindsey.norgrove@unibas.ch

1 Department of Environmental Sciences (Biogeography), University of Basel, St Johanns-Vorstadt 10, 4056 Basel, Switzerland

2 University of Colorado, Museum of Natural History, 1030 Broadway, Boulder, CO 80309, USA
Keywords Agroforestry systems · Biodiversity function · Farmer management practices $\cdot$ Agriculture $\cdot$ Landscape management

\section{Introduction}

Tropical landscape management has two pressing needs - the production of food and goods to sustain rural livelihoods on the one hand, and the conservation of biodiversity on the other hand. Agroforestry is a land use system that has raised huge interest in this respect, by agronomists and conservationists alike, as it may hold potential to reconcile these two seemingly opposing demands. Agroforestry preserves, most probably, much more of the (usually forest-bound) biodiversity than would the conversion of forests to non-forest agricultural systems. At the same time, there may be an economic benefit in maintaining high biodiversity, hence many beneficial ecological functions, in an agricultural system. This hope is sustained by experimental evidence from temperate-region grassland systems that showed a beneficial effect of biodiversity on biomass production [1]. Data from tropical biomes, particularly the humid forest zone, are scarce [2]. Agroforestry systems have been intensely studied in recent times, but due to the interdisciplinary, in parts policy-oriented nature of the topic, it is not clear what claims are backed up by solid empirical knowledge.

\section{What Is Agroforestry?}

A simple definition of agroforestry is the use of trees in agricultural systems. More precisely, agroforestry has been defined as an intimate association of a minimum of two plant species of which at least one is a woody perennial, in a spatial mix with interactions through environmental processes or 
management [3]. More recent definitions have become less exclusive (Table 1). Many traditional farming systems fall into these categories, as tropical smallholder farmers have traditionally husbanded trees among their crops [9].

\section{Defining the Scope of Tropical Agroforestry Systems with Major Groupings}

Tropical agroforestry systems can be categorized along a gradient determined by whether they include planted timber trees, non-planted timber trees, or other trees and shrubs and consequently whether the economic focus is more on forestry or on agriculture. They can also be classified by the length of the tree-crop interface. However, systems are extremely variable and can be included in multiple categories (Fig. 1). Some important types of agroforestry systems are described below (see also Table 2).

Shifting cultivation (or "slash-and-burn," swidden) systems are characterized by alternated phases of cropping and fallowing, with the length of the fallow period exceeding greatly the length of the cropping period. During the fallow phase, soil nutrients are restored to allow low-input farming during cropping phases. Typically, an area of forest or fallow is partially cleared during the dry season and the cut vegetation is left to dry [10]. Remnant forest trees are often retained in the field [11-13], a practice that is often enshrined in traditional laws (e.g., for Central Africa) [14, 15]. Farmers then burn the debris and, after the first rains, cultivate the field. After a short cropping phase, the land is abandoned to a long fallow phase. Shifting cultivation has been in existence for millennia [16]. It is common across the humid tropics [17••], particularly in areas with low human population density. Recent population growth has led to shorter fallowing phases in some parts of the world $([17 \bullet \bullet])$ and is assumed, unless management practices are adjusted, to result in a loss of sustainability and consequently create increases in demand for land to maintain production.

Homegardens comprise multi-purpose trees or shrubs (used, e.g., for fruits and firewood) grown with a large range of annual crops and vegetables. They have high levels of organic inputs, such as small livestock manure and kitchen waste [18]. Homegardens are distinguished from other agroforestry systems by being permanent, clearly delineated, and located near homesteads.

In improved fallows, trees or shrubs are tended or planted with the aim of either economically enriching the fallow so that more products (e.g., firewood and medicinal plants) are produced (in addition to crops), or biologically enriching the fallow by, for example, adding trees that improve soils (e.g., nitrogen fixing). Systems using herbaceous legumes, such as Mucuna spp. or Pueraria phaseoloides, for this and other purposes, are functionally similar although they are not regarded as agroforestry.

In alley cropping, food crops (e.g., maize) are grown between hedges of trees or shrubs, usually legumes (in Africa, e.g., Leucaena leucocephala, Calliandra calothyrsus, Gliricidia sepium, and Flemingia macrophylla) that are pruned during the cropping phase. Alley cropping is often attributed to B. T. Kang [19], who developed this system in SW Nigeria in the 1970s. However, there are examples of similar smallholder systems that preceded it, such as the use of Dactyladenia barteri in fields in SE Nigeria [20] and L. leucocephala in Timor, Indonesia [21]. In the Northwest Region of Cameroon, farmers plant lines of Tephrosia vogelii into their maize fields, stating that it suppresses the weed Imperata cylindrica (L. Norgrove, unpublished data).

Agrisilviculture (or agrosilviculture) distinguishes agroforestry systems that include planted timber trees as well as other perennial or annual crops. Two main types are common: (1) temporary intercropping systems (or taungya), in which food crops are grown between timber tree saplings before canopy closure; or (2) longer-term associations between timber trees and, usually, perennial crops, particularly Musa spp.:

Table 1 Definitions of agroforestry by the minimum number and type of components, the requirement for spatial or only temporal mixing, and the degree of interaction between components (updated after [8])

\begin{tabular}{|c|c|c|c|c|c|}
\hline & Huxley (1983) [3] & Young (1989) [4] & Nair (1991) [5] & Sanchez (1995) [6] & $\begin{array}{l}\text { Zomer et al. } \\
\text { (2009) [7] }\end{array}$ \\
\hline Minimum components & $\begin{array}{l}\text { Minimum of two plant } \\
\text { species of which at least } \\
\text { one is woody. Animals } \\
\text { optional }\end{array}$ & $\begin{array}{l}\text { Woody perennial } \\
\text { and crop and/or animal }\end{array}$ & $\begin{array}{l}\text { Trees (shrubs?) } \\
\text { crop and/or animal }\end{array}$ & $\begin{array}{l}\text { Tree and crop } \\
\text { and/or animal }\end{array}$ & $\begin{array}{r}\text { Woody perennials } \\
\text { included within } \\
\text { farming system }\end{array}$ \\
\hline $\begin{array}{c}\text { Spatial mix required or } \\
\text { only time sequence? }\end{array}$ & $\begin{array}{l}\text { Spatial mix required } \\
\text { (not time sequence) }\end{array}$ & $\begin{array}{l}\text { Spatial mix or time } \\
\text { sequence possible }\end{array}$ & ns & ns & ns \\
\hline $\begin{array}{l}\text { Types of interactions } \\
\text { required }\end{array}$ & $\begin{array}{l}\text { Interactions through } \\
\text { environmental processes } \\
\text { or management }\end{array}$ & $\begin{array}{l}\text { Both ecological and } \\
\text { economic interactions }\end{array}$ & Not specified & $\begin{array}{l}\text { Interactions } \\
\quad \text { (competition) }\end{array}$ & ns \\
\hline
\end{tabular}

$n s$ not stated 


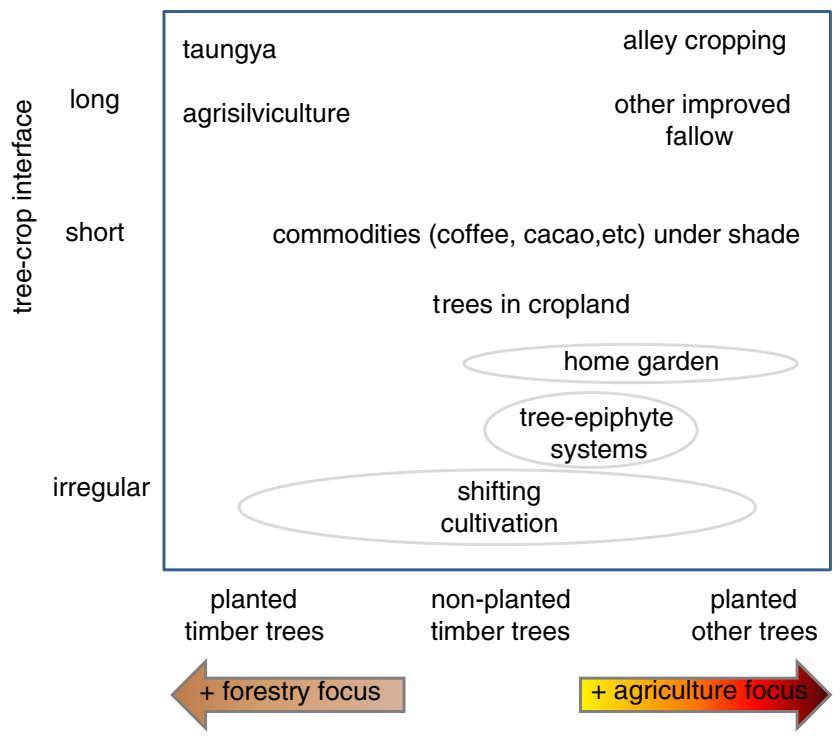

Fig. 1 Depiction of selected tropical agroforestry systems along a forestry to agriculture gradient and according to the type and length of the tree-crop interface

1. Taungya was used in the seventeenth century by the Yao and Miao peoples in southern China to cultivate the conifer Cunninghamia lanceolata [22]. In nineteenth century Burma, the taungya system was used to produce teak (Tectona grandis) by the British Colonial Service while local farmers planted sweet potatoes, cotton, and chillies between the tree seedlings [23]. The taungya system has spread worldwide and is usually institutionalized and instigated by forestry departments which permit smallholder farmers to crop between trees, saving on the labor cost of weeding the plantation. While the system has persisted, it has been severely criticized by some as being exploitational [24]. Indigenous taungya systems, designed and controlled by smallholders, are rare but do exist. For example, teak is grown with upland rice in Lao PDR [25] or with other food crops in Indonesia [26, 27].

2. There are only few references on traditional long-term associations between planted timber trees and crops. In the "damar" (resin) system of Indonesia, Shorea javanica is planted by smallholder farmers for timber and resin production, combined with food crops and fruit trees [28-30].

Shade commodities: Traditionally, smallholders have grown rubber and stimulants such as cacao, coffee, and tea, under shade trees, whether planted or retained after partial forest clearance. Today, these crops are major agricultural commodities with globally combined production area amounting to approximately $36 \times 10^{6}$ ha (data from [31]). Although often managed in industrialized plantations, they are partly still grown under shade from timber trees.

\section{Evaluating Benefits and Costs of Agroforestry}

Agroforestry systems can vary in scale (e.g., smallholder farming vs. industrialized plantation), and socioeconomic characteristics vary accordingly. However, regardless of scale, agroforestry systems will generally have higher product diversity and a wider range of planting, weeding, and harvesting times than an equivalent monocrop system. This leads to potential advantages for smallholder farmers in particular, such as (1) reduced risk of total crop failure (as the risk is spread between many species, akin to the "spatial insurance hypothesis" [63]); (2) increased diversity of products, hence improved nutrition for subsistence farmers; (3) less vulnerability to market price changes (for cash crops); (4) better distributed labor demands over the year; and (5) reduced seasonality of income (for cash crops). Apart from these, there are potentially positive effects on yields due to ecological effects such as complementarity and facilitation.

\section{Complementarity}

A central hypothesis in agroforestry is that "the benefits of growing trees with crops will only occur when the trees are able to acquire resources of water, light and nutrients that the crops would not otherwise acquire" [64]. Trees and crops are complementary if they exploit more of the factors limiting growth, when grown together [65]. Where the different components have different root and stem architectures, or when their growth demand peaks are at different times, they are more likely to show complementarity [65-67]. For example, many food crop annuals are shallow rooting. In combination with a deep-rooting tree, more of the available soil volume is explored, and a greater amount of available water and nutrients accessed [68]. The most common mechanism for higher productivity in mixtures is the temporal sharing of resources. For example, mango trees (Mangifera indica) assimilate and produce leaves during the dry season when associated crops have been harvested or have reduced demands.

\section{Facilitation}

Different species may not only be unaffected in their growth by each other's presence, they may even benefit. A modification of the environment by one partner with benefits for the other describes the "facilitative production principle" [69]. For example, a reduction in light intensity may, under tropical, high-radiation conditions, have positive growth effects by, for example, avoiding stomatal closure at midday [70]. In some crops such as plantain (Musa spp.), light saturation density of 


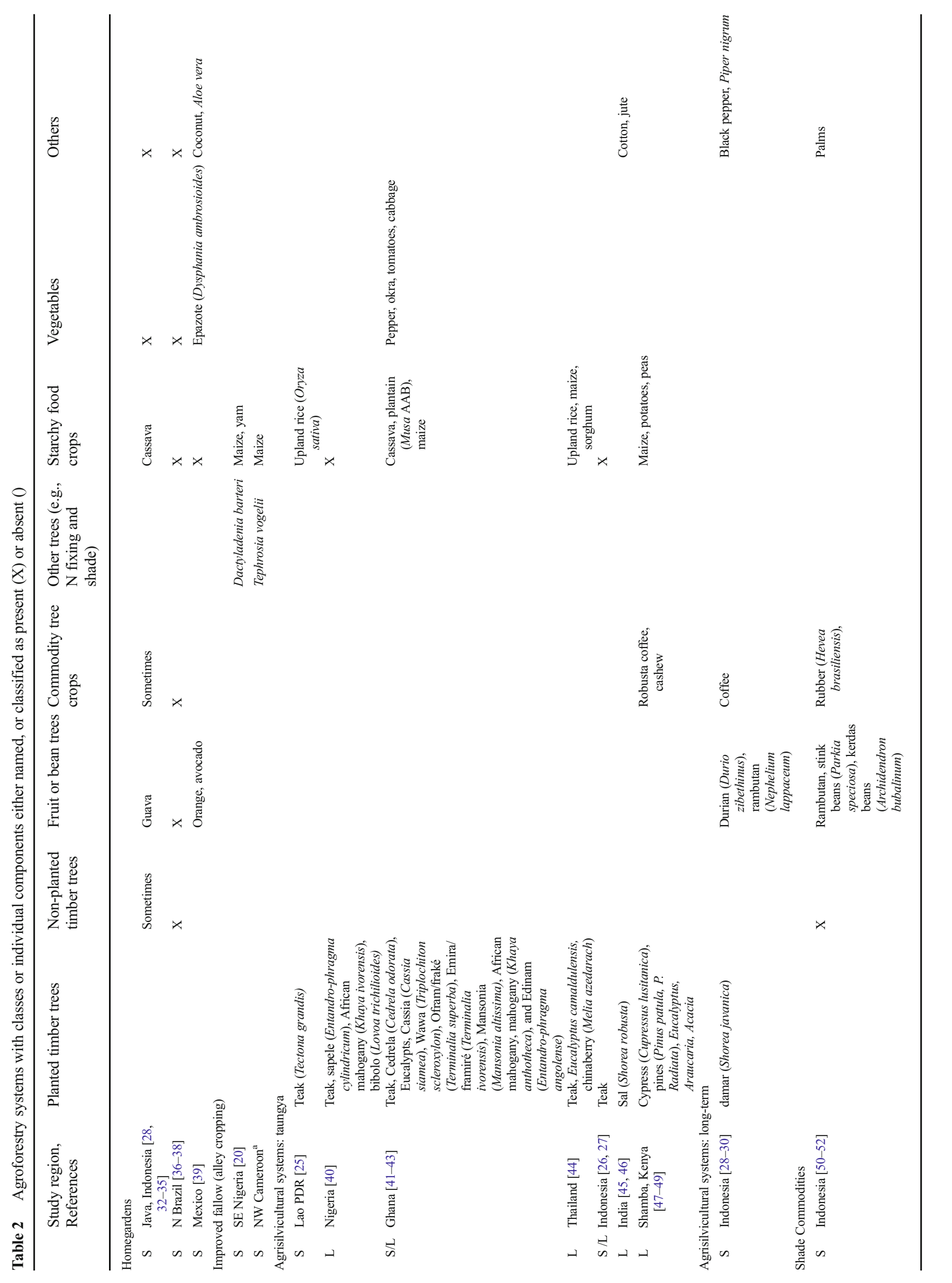


leaves can be low and full light can lead to photorespiration rather than growth [71]. Shade can also alter pest and disease dynamics. Black sigatoka (Mycosphaerella fijiensis), the most important Musa disease globally, can be reduced under shade [72].

An agroforestry tenet is that trees perform a facilitative function by improving or maintaining soil fertility, in addition to the improved water and nutrient capture mechanisms mentioned above. Leaf litter cover, tree root decomposition, and the more stable soil microclimate created may maintain soil organic matter and also improve soil biological activity [73]. However, many of these assumptions have not been empirically proven, or only under specific circumstances [6]. Many data demonstrating positive effects of trees on soil qualities have been collected from natural [74], rather than planted tree systems. Therefore, it is not possible to clearly assess causalities, i.e., whether the trees improved the soil or whether good soils allowed the germination and growth of the trees.

\section{Costs}

There are also potential disadvantages of agroforestry, particularly for large-scale plantations. Among them are (1) difficult application of machinery for harvesting and planting, (2) greater requirement for technical knowledge, and (3) less benefits from "economy of scale" effects $[75,76]$, e.g., in processing, transporting, and harvesting harvests. Furthermore, whether yields actually do increase, or possibly even decrease, is far from certain and requires quantitative study.

\section{Cost/Benefit Analysis}

The evaluation of yield benefits and, ultimately, economic advantages of agroforestry over other forms of production is notoriously difficult. The criterion most frequently used to judge these quantitatively is the land equivalent ratio (LER; see text box) [77]. It quantifies whether mixed cultivation yields more, or less, than what could be harvested in a monoculture. However, the performance of an agroforestry system varies locally due to the selected species' combination, absolute and relative densities, and the limiting factors of the selected environment. The non-linearities inherent to economic as well as ecological processes (such as complementarity and facilitation) mean that outcomes could be very different depending on the exact mix and it is difficult to separate the effects of diversity, composition, and management. It is therefore challenging to evaluate systems empirically in any general, transferable way, particularly systems with many components, and such attempts would require large experimental designs. For example, Leakey (2014) [78] discusses the uses of Nelder fan [79] and complex replacement series designs for determining optimum shade tree and shrub mixes in a cacao agroforestry trial. The timeframe of evaluations may also 
matter-for example, in grassland experiments $[1,80]$, particular monocultures in particular years performed better than more diverse systems, although longer-term average production of diverse communities always exceeded monocultures. When such ideas are applied to tree systems with longer growth cycles, even longer-term experiments are required and these should be a priority in the upcoming decades.

Furthermore, metrics such as the LER do not take account of the economic values of the different components and the outcome with the highest LER may not be the same as the one with the highest value [81]. Indeed, where the role of trees is not to produce a marketable product but simply to provide benefits such as, e.g., maintain soil fertility or conservation of biodiversity (e.g., alley cropping), the adoptability of the system is greatly constrained. The "yield" of the hedgerow (e.g., its pruning) is not intrinsically of interest to farmers (although it can be used as mulch for the crop). For an alley cropping system to be successful economically, either the yield of the food crop would need to exceed that of a monoculture in the long term (despite reduced production area), or there needs to be an indirect economic benefit (e.g., conservation subsidies and offsets). In contrast, where the tree component produces edible or marketable products, farmers can be expected to be more tolerant of lower yields of their food crops, as they may gain economically, overall. Such calculations also need to take into account that smallholder farmers typically have short-time horizons and thus apply high discount rates [82], partly due to commonly high levels of tenure insecurity (for example, [83]), a disincentive to planting trees [84]. Thus farmers may favor short-term crops over trees and fast-yielding perennials, such as early fruiting trees, over timber trees with longer production cycles. Yet other authors have shown that incorporating trees into systems can reduce production risks and increase profitability compared to crop monocultures even under high discount rates [85].

Text box: The land equivalent ratio (LER)

LER allows the quantification of relative yield losses or benefits due to multi-cropping (e.g., a food crop and a tree) compared to monocrop systems [77]. It is calculated as

$$
L E R=\frac{I_{\mathrm{t}}}{M_{\mathrm{t}}}+\frac{I_{\mathrm{f}}}{M_{\mathrm{f}}}
$$

where

$I_{\mathrm{f}}=$ yield (per ha and unit time) of food crop, in mixed cultivation

$I_{\mathrm{t}}=$ yield (per ha and unit time) of tree, in mixed cultivation

$M_{\mathrm{f}}=$ yield (per ha and unit time) of food crop in monoculture at optimum density

$M_{\mathrm{t}}=$ yield (per ha and unit time) of tree in monoculture at optimum density

LER can take values between 0 (no yield at all) and $>2$ (if, due to facilitation, both crops yield more than in monoculture despite sharing the available area). If LER $<1$, the system is not economically beneficial (as judged on yield alone), as monoculture of one crop could produce more. $\mathrm{LER}=1$ indicates yield equivalence of the two crops, i.e., losses in one crop are perfectly balanced by gains in the other crop. If LER $>1$, the multi-crop system is more productive than monoculture.

\section{Biodiversity Function in Agroforestry Systems and Relevance for Smallholder Farmers}

Apart from research assessing crop yield benefits of agroforestry systems, recent work has included potential biodiversity conservation benefits in agroforestry systems. For example, Leakey (2014) [78] collated data on biodiversity in tropical agroforestry systems as part of a more general review. Bhagwat et al. (2008) [86] focused on the potential for tropical agroforestry to maintain species diversity. Scales and Marsden (2008) [87] reviewed 52 studies that compared diversity indices between tropical agroforests and primary forest, and 27 studies that compared different types of agroforest. However, neither Bhagwat et al. (2008) [86] nor Scales and Marsden (2008) [87] distinguished between different types of biodiversity from the farmers' utilitarian perspectives or assessed productivity data to test for a relationship between biodiversity and yield. They also did not consider the experimental designs to assess whether any confounding factors were present. For example, studies comparing the different stages of a land use sequence can either sample the same site repeatedly through the various phases (type I "chronosequence" data), or different sites in different stages of the succession can be compared at the same time (type II "space-for-time" or "false chronosequence" data) [88]. Type I chronosequence data collection requires large plots and is expensive, yet it is accurate and unequivocal. Drawbacks of type II studies include spatial variation [89] and, often, unwarranted assumptions about site history $[90 \bullet \bullet$. Furthermore, type II space-for-time studies comparing farmers' fields and fallows with remaining forest remnants rely on the farmer having randomly selected his plots, an unlikely condition as farmers have developed appropriate criteria to select the most productive fallows [91].

\section{Resilience of Biodiversity in Tropical Agroforestry System}

Resilience is the capacity of an ecosystem to return to the precondition state following a disturbance, including maintaining its essential characteristics such as taxonomic composition, structures, ecosystem functions, and process rates [92, 93]. Applying this concept to agroforestry systems can imply (1) that these systems have features that allow a recovery of biodiversity back to levels found in the previous land use system, prior to the disturbance of land conversion, and (2) that management features of the agroforestry system are sufficiently benign to avoid irreversible changes during its lifespan. Tittonell (2014) [94] has recently applied the resilience concept to tropical agroecosystems in Africa. Trenbath (1985) [95] developed a simulation model detailing how changes in management practice in shifting cultivation systems might alter succession of the future fallow. His model detailed how tree biomass and grass biomass may change under intensification comprising two stability domains with a separatrix. He 
postulated that with repeated cropping cycles and shortening fallow phases, a point will be reached at which tree regeneration fails completely and the system will move to the grassland domain. This would have severe implications for shifting cultivators as the utilitarian functions of forest fallows, such as accumulating biomass and shading out agricultural weeds [96], would be lost, as well as their role as a biodiversity repository for forest species. More recently, a similar model to the Trenbath tree-grass model has been developed [97]. However, none of these models has been tested empirically, and the tipping point at which intensification creates a regime shift, as well as the dominant factors determining such a shift, has not been identified. Thus, as there is only limited empirical understanding of resilience in agroforestry systems, it is difficult to test and it may be premature to apply this concept based on assumptions alone.

\begin{abstract}
Aims
In the next section, we assess and collate the results of peerreviewed scientific studies on biodiversity of different taxa in agroforestry systems, to assess the relevance and utility from the viewpoint of the smallholder farmer, to assess how useful they are in deciding how effective the agroforestry system is in conserving biodiversity compared with a forestry agricultural landscape mosaic, and what is known about the relationship with productivity. We put particular emphasis on evaluating the evidence base for the beneficial role of biodiversity on yield and farm-level economy, which is the crucial argument for the high regard that agroforestry has. To assess the resilience of biodiversity in agroforestry systems, we used papers that examined changes over time within a particular system and those from shifting cultivation studies that assessed the residual management effects of the previous cropping phase.
\end{abstract}

\section{A Quantitative Review of Peer-Reviewed Studies on Biodiversity Function in Tropical Agroforestry Systems}

\section{Methods: Literature Search and Processing}

We conducted a literature search in SCOPUS on 1 June 2015 by searching for the following combinations of words in the title, abstract, or keywords: (agroforestry OR swidden OR "hedgerow intercropping" OR "alley cropping" OR agrosilviculture OR home garden OR "shifting cultivation" OR "planted fallows" OR "improved fallows" OR taungya OR agrisilviculture OR "slash and burn") AND (biodiversity OR "ecosystem function" OR diversity OR "species richness" OR "Shannon-Wiener index" OR "Simpson index") AND (tropic*). We limited our search to journal articles within environmental and agricultural sciences. There was no time limitation.

The initial search resulted in 277 articles. We then manually excluded articles, such as review articles, those from outside the geographical tropics, those that did not contain biodiversity data, and two articles that we were unable to access. To limit the enormous potential scope, we also excluded articles where animals were a major component of the system, such as sylvopastoralism, leaving 146 articles. We extracted data on the following topics from these studies.

(1) To categorize different types of biodiversity functions in agroforestry systems, we used a system developed by Biala et al. (2005) [98] that can be adjusted to adequately describe the biodiversity of agroforestry systems:

i. Planned cultivated biodiversity, consisting of the crop mix planted by the farmer

ii) Spontaneous volunteer biodiversity, i.e., marketable or useful species that were not planted, but are tended by the farmer

iii. Within-system functional biodiversity, e.g., regulators of soil fertility, natural enemies of crop pests, decomposer microbes, nitrogen fixers, pollinators of food crops, and trees present within the agroforestry system

iv. Out-of-system functional biodiversity, which has a landscape-wide benefit in adjacent cropping systems, such as pollinators of crops or predators of crop pests not in the agroforestry system but in other production systems in the landscape

v. Heritage biodiversity, i.e., biodiversity not known to be directly linked to the functioning of the agroforestry system or production systems in the landscape, but of conservation value

Some studies evaluated data for several of these categories. In such cases, we assigned the most valuable function, from a utilitarian farmer's perspective, to that study (i.e., highest: planned cultivated biodiversity, lowest: heritage biodiversity).

Other variables of interest were (2) country (for insular Southeast Asia: island); (3) taxon studied; (4) type of agroforestry systems tested; (5) whether forest and agricultural controls were included; (6) the factors or covariables assessed, if any, and whether they related to smallholder management (if any); (7) whether the study was experimental (planted assemblages after randomly assigning plots, compared with agricultural and forestry controls), semi-experimental (some treatment imposed within the agroforest to elucidate functions), or descriptive (e.g., an existing type II "false chronosequence"); (8) whether productivity data (crop yields, economic value, carbon stocks) were presented; and (9) what the relationship of biodiversity and productivity was (if investigated). 
We identified a subset of papers that, in addition to comparing different land use systems, assessed the effects of farmer-relevant management practices within a system or looked at various landscape variables and categorized them by the type of agroforestry system investigated. We also identified those papers comparing similar systems in different stages of succession to estimate biodiversity resilience through time or those that looked at residual effects of management practices in the crop phase on the recovery of the following fallow. Of these, we only included studies that contained at least three age classes. Where secondary forests were mentioned without specifying age, we coded the age as 35 years. Similarly, primary forest and old growth forest were specified as 100 years old. We selected fallow succession studies that had a primary forest control. Of those, we calculated the proportion of recovery of species richness or species number, by comparing with the primary forest control. This is a simplistic measurement, yet it was chosen as many papers did not assess more complex indicators such as changes in functional composition. We then tested the significance of linear regressions of species against age and separated those that were significant. The age at which $80 \%$ of species recovery would be obtained was estimated from the linear regressions obtained.

\section{Results}

Categorizing Studies by Location, System, Taxon, and Other Features

Studies found were from across the Americas, Africa, and Asia with Mexico, Costa Rica, Brazil, Cameroon, and Sulawesi (Indonesia) having eight or more studies (Fig. 2a). One hundred twenty studies ( $82 \%$ ) were from humid forest ecoregions, 11 from sub-humid forest, 6 from montane forest, 1 from seasonally dry forest, 3 from the forest-savannah transition zone, and 5 from dry forest. The majority of studies assessed the biodiversity of taxa assumed to be of positive functional use to the farmer ("within-system"; Fig. 2b). Almost half of studies investigated the diversity of plants, while Hymenoptera (mainly ants) and birds were other major groups (Fig. 2b). Over a quarter of studies described biodiversity in shifting cultivation systems, and approximately half of studies described shaded commodity crops, predominantly cacao and coffee. Other shaded commodity systems were dominated by rubber [99, 100], tea [53], coconut [101], and cardamom [102, 103]. Other systems, such as homegardens, agrisilviculture, and improved fallow were rarely studied. We did not find any study on biodiversity in taungya systems. Studies were predominantly of descriptive research design (Fig. 2b).
Biodiversity in Relation to Control Habitats and Yield

More studies contained forest controls (63\%) than agricultural controls (20\%), and only $19 \%$ contained both types of controls (Table 3). However, controls were not usually composed of the individual components of the agroforestry systems; thus, it was not possible to conduct an LER-type analysis (see text box) to consider whether more biodiversity would be retained by the agroforestry system in contrast to its monocropped constituent parts.

Nevertheless, many agroforests (approximately $2 / 3$ ) had significantly lower tested diversity than forest. For the remaining studies, there was no significant difference between agroforests and forests, however, this might be because of high variability and insufficient sampling and cannot be interpreted as meaning that there is no biodiversity loss. Less than half $(41 \%)$ had significantly higher diversity than the agricultural control (Table 3).

Seventeen papers contained productivity data. Of these, only one study demonstrated a positive relationship between the number of cultivated species and total system (trees + crops) biomass production [124]. This study compared three tree species each planted in either a tree monoculture or intercropped in a polyculture with crops. Three years after planting, total system biomass production was increased in the polyculture versus the monoculture for the tree species Cedrela odorata and Cordia alliodora but was not significantly different for Hyeronima alchorneoides [124]. One paper found a negative effect of diversity in which higher cacao yields were associated with low richness of forest tree species [121]; however, these data were derived from farmers' shaded cacao farms where the diversity of shade trees was confounded with shade level and, therefore, results simply demonstrate that very high shade levels can limit cacao production and do not test diversity per se. Four studies tested the relationship but found no significant effect (Table 3). The remaining 11 studies presented data but did not explicitly address the link between diversity and yield or carbon stocks.

\section{Biodiversity in Relation to Management}

Studies on the effects of management within systems were few, with most of them addressing shaded commodity crops and analyzing species richness as a response. For cacao, the effect of shade level was the factor most intensively studied (13 studies) while the density of flowering plants, weeding frequency, and the application of fungicide, insecticide, or nitrogen fertilizer were addressed in single studies only (Table 4). Many of the results were from the same, large project in Sulawesi; others were from Ecuador, Cameroon, and Brazil. No study found a negative correlation between shade level and biodiversity, there were eight occurrences of significantly positive effects, and 17 results were non-significant. Shade levels and tree diversity were, generally, positively correlated. Shade effects were always 


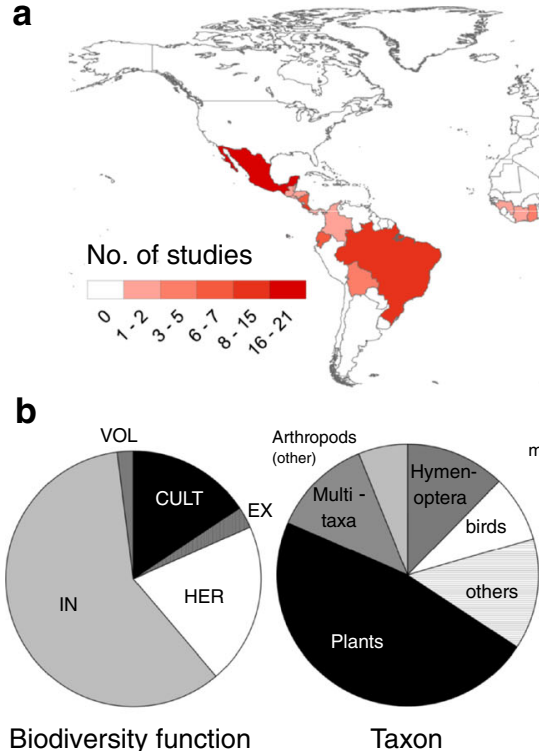

Fig. 2 Properties of 146 reviewed studies on tropical agroforestry and biodiversity function. a Location of studies by country (in insular Southeast Asia by island). b Frequencies of studies by biodiversity function $(\mathrm{CULT}=$ planned, cultivated biodiversity; VOL = spontaneous, volunteer biodiversity of use for the farmer; IN = biodiversity of positive, functional use for the farmer within the system

positive on the diversity of birds; non-significant on amphibians, reptiles, and (mostly) invertebrates; and mixed on non-woody plants. However, these results are confounded by the higher probability of having more tree species when shade levels and therefore densities are higher, as data were mainly from descriptive studies of existing farmer managed systems rather than from planted experimental systems explicitly testing shade and diversity effects.

There was not sufficient information in the papers to assess which shade level was optimum. For coffee, some studies also investigated shade level as well as the distance from the

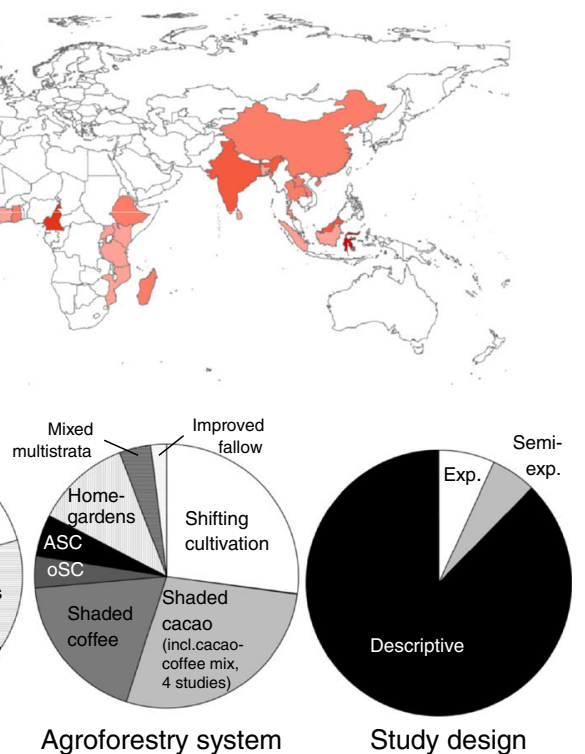

(e.g., soil fertility, pest control, and pollination); EX = biodiversity of positive, functional use outside the study system; HER = heritage biodiversity (without direct, studied link to study system), taxon, agroforestry system (ASC $=$ agrisilviculture; oSC $=$ other shade commodity), and study design

agroforestry system to the nearest old growth forest (Table 5). Shade level generally had a non-significant effect, although it was only tested on ants and bats. Distance to the forest was negatively related to species richness of invertebrates.

\section{Resilience}

For assessments of biodiversity resilience (i.e., changes through time), we found one paper on homegardens in

Table 3 Number of studies with controls (agr. = agriculture), biodiversity differences of agroforestry compared to controls, and diversity-productivity effects, classified by type of agroforestry system

\begin{tabular}{|c|c|c|c|c|c|c|c|c|c|c|}
\hline \multirow[b]{2}{*}{ System type } & \multicolumn{4}{|c|}{ Control habitat present } & \multicolumn{3}{|c|}{ Biodiversity difference } & \multicolumn{3}{|c|}{ Relationship biodiversity and productivity } \\
\hline & $N$ & Only forest & Only agr. & Both & $N^{\mathrm{a}}$ & Lower than forest & Higher than agr. & $N$ & Positive & Negative \\
\hline Shifting cultivation & 42 & 23 & 3 & 8 & - & - & - & 0 & 0 & 0 \\
\hline Homegarden & 18 & 3 & 0 & 2 & 0 & 0 & 0 & 1 & 0 & 0 \\
\hline Agrisilviculture & 8 & 2 & 0 & 1 & 0 & 0 & 0 & 1 & 1 & 0 \\
\hline Shade commodities & 78 & 36 & 3 & 6 & 14 & 8 & 6 & 4 & 0 & 1 \\
\hline Other & 9 & 3 & 0 & 0 & 2 & 2 & 0 & 0 & 0 & 0 \\
\hline Total & 155 & 74 & 8 & 24 & 16 & 10 & 6 & 6 & 1 & 1 \\
\hline
\end{tabular}

Note that the total surpasses the number of reviewed studies (146) as some papers presented data from several systems. The significance of effects was based on error probabilities given in papers $(P \leq 0.05)$ or estimated from graphic data representation (e.g., non-overlap of $2 * \mathrm{SE}$ ). Papers used for biodiversity comparison: [53, 104-110, 111••, 112-118]. Papers used for biodiversity-productivity relationship: [119-124]. Two "others" were both semi-experimental studies on Quesungual slash-and-mulch agroforestry [111••] and fruit trees under shade [107]

$N$ number of tests with relevant data

${ }^{a}$ Studies on fallows in shifting cultivation systems were excluded from this comparison 
Table 4 Management influences tested on biodiversity in shaded cacao systems

\begin{tabular}{|c|c|c|c|c|c|c|c|}
\hline Taxon, reference & Locality & $\begin{array}{l}\text { Shade } \\
\text { level }\end{array}$ & $\begin{array}{l}\text { Density of } \\
\text { flowering } \\
\text { plants }\end{array}$ & $\begin{array}{l}\text { Fungicide } \\
\text { application }\end{array}$ & $\begin{array}{l}\text { Insecticide } \\
\text { application }\end{array}$ & $\begin{array}{l}\text { Weeding } \\
\text { frequency }\end{array}$ & $\begin{array}{l}\text { Fertilizer } \\
\text { app N }\end{array}$ \\
\hline \multicolumn{8}{|l|}{ Vertebrates } \\
\hline Birds [125] & $\mathrm{E}$ & $+\mathrm{ve}$ & - & - & - & - & - \\
\hline Birds [126] & SI & $+\mathrm{ve}$ & - & - & - & - & - \\
\hline Amphibians [127] & SI & ns & - & - & - & - & - \\
\hline Reptiles [127] & SI & ns & - & - & - & - & - \\
\hline \multicolumn{8}{|l|}{ Invertebrates } \\
\hline Parasitoids [128] & $\mathrm{AB}$ & $+\mathrm{ve}$ & - & - & - & - & - \\
\hline Bees [129] & SI & ns & $+\mathrm{ve}$ & - & - & - & - \\
\hline Scarabaeid beetles [130] & SI & ns & - & - & - & - & - \\
\hline Butterflies [126] & SI & ns & - & - & - & - & - \\
\hline Canopy beetles [126] & SI & ns & - & - & - & - & - \\
\hline Bees [126] & SI & ns & - & - & - & - & - \\
\hline Wasps [126] & SI & ns & - & - & - & - & - \\
\hline Parasitoids [126] & SI & ns & - & - & - & - & - \\
\hline Ants [131] & SI & ns & - & - & - & $-\mathrm{ve}^{\mathrm{a}}$ & ns \\
\hline Ants [132] & SI & ns & - & - & ns & - & - \\
\hline $\begin{array}{l}\text { Lower canopy beetles } \\
\text { [133] }\end{array}$ & SI & ns & - & - & - & - & - \\
\hline Lower canopy ants [133] & SI & ns & - & - & - & - & - \\
\hline Earthworms [54] & $\mathrm{CC}$ & - & - & ns & - & - & - \\
\hline Termites [54] & $\mathrm{CC}$ & - & - & ns & - & - & - \\
\hline Ants [134] & $\mathrm{CC}$ & $+\mathrm{ve}$ & - & - & - & - & - \\
\hline \multicolumn{8}{|l|}{ Plants } \\
\hline Trees [128] & $\mathrm{AB}$ & $+\mathrm{ve}$ & - & - & - & - & - \\
\hline Trees [126] & SI & ns & - & - & - & - & - \\
\hline Trees [134] & $\mathrm{CC}$ & $+\mathrm{ve}$ & - & - & - & - & - \\
\hline Epiphytic ferns [135] & SI & ns & - & - & - & - & - \\
\hline Herbs [136] & SI & ns & - & - & - & - & - \\
\hline Herbs [134] & $\mathrm{CC}$ & $+\mathrm{ve}$ & - & - & - & - & - \\
\hline Lianas [126] & SI & $+\mathrm{ve}$ & - & - & - & - & - \\
\hline Liverworts [126] & SI & ns & - & - & - & - & - \\
\hline \multirow[t]{3}{*}{ Totals by \# factors tested } & $+\mathrm{ve}$ & 8 & 1 & 0 & 0 & 0 & 0 \\
\hline & $-\mathrm{ve}$ & 0 & 0 & 0 & 0 & 1 & 0 \\
\hline & ns & 17 & 0 & 1 & 1 & 0 & 1 \\
\hline
\end{tabular}

All studies from the humid forest ecoregion

$n s$ not significant, $+v e$ significantly positive at $P<0.05,-v e$ significantly negative at $P<0.05, E$ Ecuador, $C C$ central Cameroon, $S I$ Sulawesi, Indonesia, $A B$ Atlantic Brazil

${ }^{\text {a }}$ High $\left(6\right.$ year $\left.^{-1}\right)$ or low $\left(\right.$ year $\left.^{-1}\right)$ frequency

Indonesia, with ages ranging from 10 to 80 years old [141]. They found no relationship between tree species richness and age. Three studies from Ecuador [115, 138, 142] compared active coffee plantations with those abandoned 10-15 years ago, against a forest control. Whether or not pesticides were used was not reported. Total arthropod species richness was not significantly different between forest and abandoned coffee yet significantly lower in actively managed shaded coffee. There were no differences between actively managed and abandoned coffee in adult tree species richness; however, for both tree saplings and tree seedlings, abandoned coffee had higher species richness than active coffee and was not significantly different from the forest. These results suggest that this shaded coffee system was relatively benign from a viewpoint of biodiversity preservation and restoration can subsequently occur back to forest levels. We found no other studies in the shaded commodity, mixed multi-strata, improved fallow, or agrisilviculture categories. 
Table 5 Management influences tested on species richness in shaded coffee systems, all from humid forest ecoregions

\begin{tabular}{lllll}
\hline Reference & Region & Taxa & Shade level & Distance to forest \\
\hline$[137]$ & Sulawesi, Indonesia & Bees & - & $-\mathrm{ve}$ \\
{$[137]$} & Sulawesi, Indonesia & Wasps & - & $-\mathrm{ve}$ \\
{$[137]$} & Sulawesi, Indonesia & Parasitoids of bees and wasps & - & $-\mathrm{ve}$ \\
{$[138]$} & Ecuador & Ants & $\mathrm{ns}$ & - \\
{$[139]$} & Chiapas, Mexico & Bats & ns & - \\
{$[140]$} & El Salvador & Trees $>2$-m height & $+\mathrm{ve}$ & $\mathrm{ns}$ \\
\hline
\end{tabular}

$n s$ not significant, +ve significantly positive at $P<0.05,-v e$ significantly negative at $P<0.05$
All remaining papers on resilience dealt with temporal changes in biodiversity during the fallow period in shifting cultivation systems, and most of these focused on the effect of the age of the current fallow (Table 6). Of papers including at least three age categories and a primary or old growth forest, 9 studies had significant positive linear regressions between species richness and age for any particular group, while the rest were non-significant (14). The greatest proportion of significant studies was for invertebrates $(2 / 3)$, followed by "all plants" (4/7) (Table 6). With the exception of one study from the dry forest of Mexico (33 years) [90••], it took at least 48 years for species richness to approach $80 \%$ of the value of the primary forest, and this estimate did not vary consistently between taxa or ecoregion; however, the number of data points per time sequence was limited (Fig. 3).

Eight papers looked at factors other than fallow age affecting biodiversity resilience in shifting cultivation (Table 7). Factors comprised a mix of residual management effects and landscape configuration. Three out of five studies assessing landscape configuration effects suggested effects of biodiversity reservoirs (e.g., nearby old-growth forests). Three studies from humid forest ecoregions assessed the effects of the number of previous crop-fallow cycles, with one reporting a negative effect on diversity (the two others were non-significant).

Table 6 Number of studies assessing effects of fallow age on biodiversity in shifting cultivation systems

\begin{tabular}{llll}
\hline Taxon & Sig. & Not sig. & Refs \\
\hline Vertebrates & $1^{\mathrm{a}}$ & $4^{\mathrm{b}}$ & {$\left[143-145,146^{\mathrm{c}}\right]$} \\
Trees & 2 & 6 & {$[146-153]$} \\
Invertebrates & $2^{\mathrm{d}}$ & $1^{\mathrm{e}}$ & {$[100,148,154]$} \\
All plants & 4 & 3 & {$[90 \bullet \bullet, 151,155-157,158 \bullet \bullet, 159]$} \\
Totals & 9 & 14 & \\
\hline
\end{tabular}

NB studies had at least three ages classes with a primary or old-growth forest control; assessment of significance (sig., $P<0.05$ ) is based on linear regression (ordinary least squares)

${ }^{a}$ Birds

${ }^{\mathrm{b}}$ Bats, frogs and lizards, small mammals, forest birds

${ }^{\mathrm{c}}$ Compares all birds with forest birds

${ }^{\mathrm{d}}$ Beetles, butterflies

${ }^{\mathrm{e}}$ Ants
Studies testing various effects of phase durations (e.g., cropping and previous fallow) did not find significant effects, while the effect of previous tillage was negative for plant and seedbank species richness.

\section{Discussion}

Increasing agricultural production in the tropics is jeopardizing conservation aims. There is currently much discussion on how to best compromise between these seemingly antagonistic needs: the land sparing versus land sharing debate $[165$, 166]. Land sparing is achieved by intensification of crop

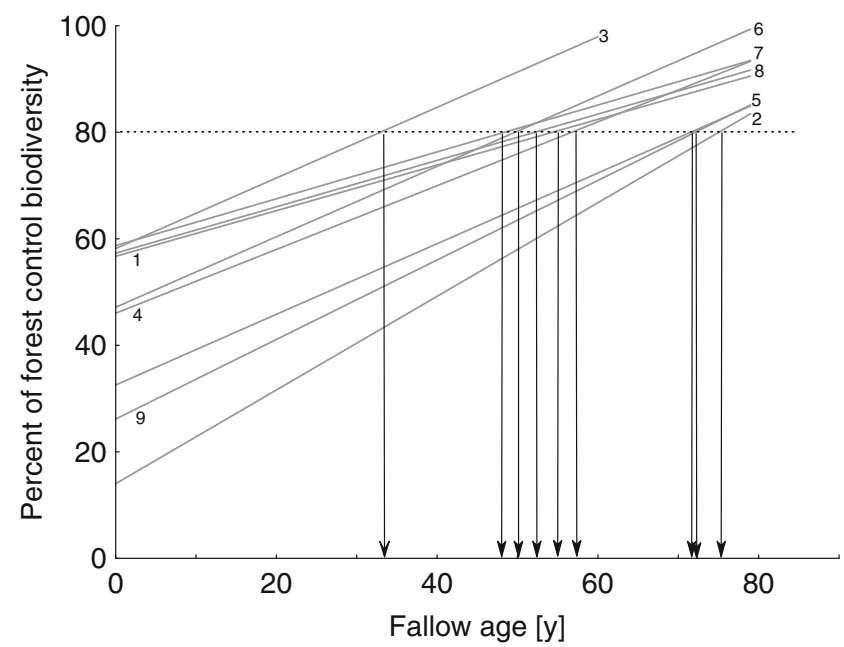

Fig. 3 Estimate of species richness recovery (in percent of old-growth control levels) as a function of fallow age. Linear regressions (OLS) were fitted to published data as a crude, preliminary representation of recovery trajectories. Arrows indicate the age at which $80 \%$ of reference biodiversity would be restored according to these functions. Numbers give taxon, locality, ecoregion, and $r^{2}$ s of linear regressions (all were significant at $P<0.05$ ): (1) trees, Hainan (China), humid forest, $r^{2}=0.99, n=4$ [147]; (2) trees, NE India, humid forest, $r^{2}=0.94, n=5$ [146]; (3) all plants, Mexico, dry forest, $r^{2}=0.47, n=15$ [90••]; (4) all plants, Madagascar, humid forest, $r^{2}=0.81, n=6$ [156]; (5) all plants, Madagascar, semi-humid forest, $r^{2}=0.99, n=5$ [158・•]; (6) all plants, Côte-d'Ivoire, semi-humid forest, $r^{2}=0.59, n=8$ [159]; (7) birds, NE India, humid forest, $r^{2}=0.81, n=5$ [146]; (8) beetles, Borneo, humid forest, $r^{2}=0.99, n=4$ [100]; (9) butterflies, Borneo, humid forest, $r^{2}=0.97, n=4[148]$ 


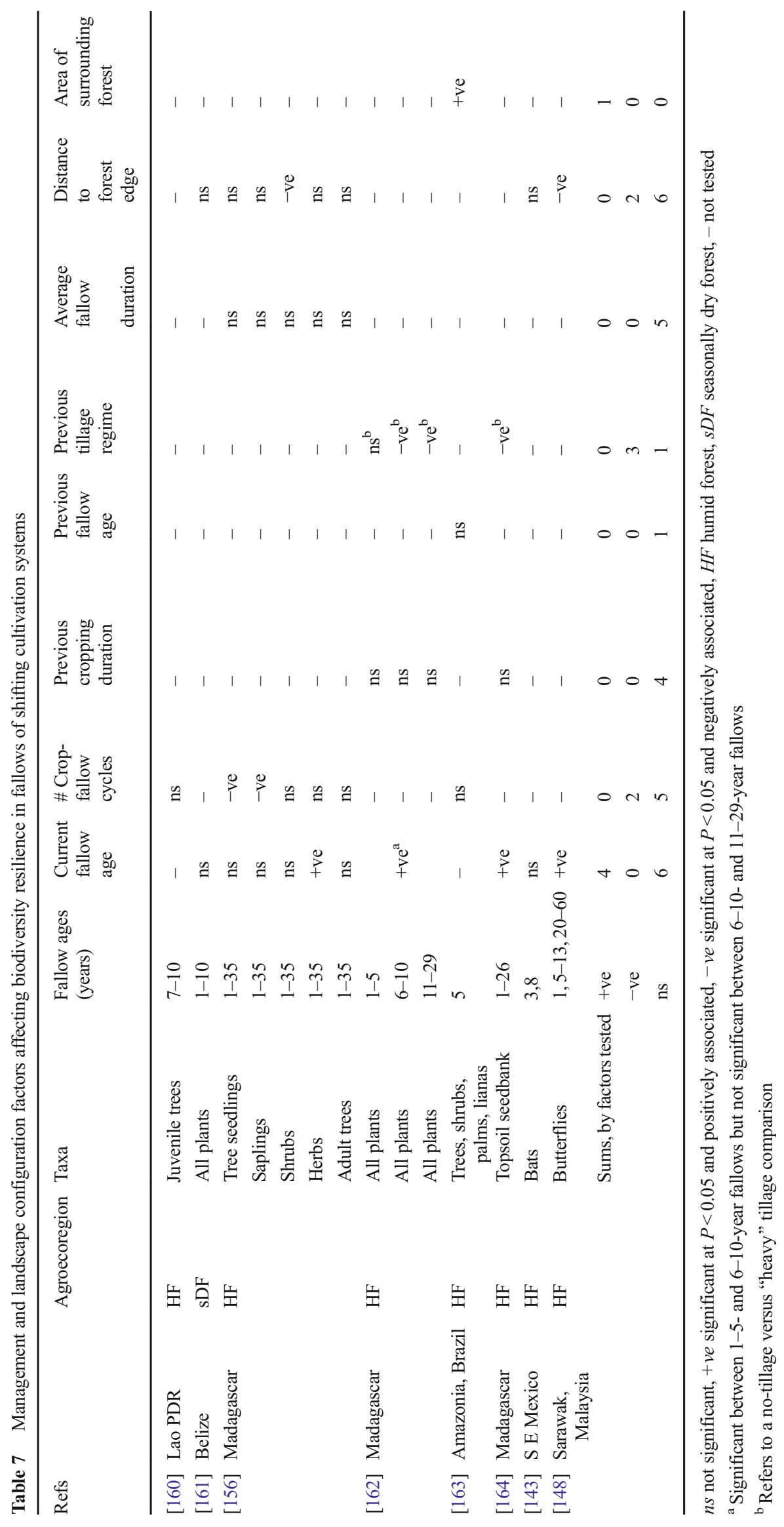


production to achieve higher yields. This saves other (e.g., forested) land for conservation purposes. Land sharing is the application of farming practices that preserve or promote biodiversity within agricultural areas, often using low levels of inputs and minimal disturbance but at the cost of lower yields and therefore a greater area requirement for equivalent production. Traditional smallholder agroforestry systems are usually perceived as a land sharing strategy [86].

While reviewing 146 original studies on biodiversity in tropical agroforestry systems, we focused on evaluating the evidence for three main conjectures in agroforestry research and policy: (1) It helps to preserve (forest-bound) biodiversity, (2) farming techniques are complementary to and not antagonistic with those promoting biodiversity conservation, and (3) there are economic advantages due to direct positive effects of biodiversity on productivity. If these conjectures are true, they provide strong arguments for environmental policies to maintain and promote agroforestry systems, in smallholder as well as plantation farming, across the tropics. A question of such global, applied relevance cannot be judged based on single studies, as they always refer to a particular system and region. As we have shown above, there is a wide variety of agricultural systems bunched together under the term agroforestry, which may react quite differently. Furthermore, single studies are prone to type I statistical error [167], hence the requirement to assess results from multiple studies.

\section{Methodological Issues}

Providing research results in a manner that facilitates review and meta-analysis is of high value. We noticed a relatively poor documentation of relevant factors in many studies, which may partly stem from the interdisciplinary nature of the research topic (i.e., ecology and agronomy; e.g., lacking information on age of system; planting densities; husbandry techniques such as weeding and pruning, etc.; and variety of crops such as coffee and cacao used, which may have different shade responses) [168]. Similarly, reporting on statistical test results was often not sufficient to carry out formal, quantitative meta-analyses [169], and the analysis of biodiversity in some papers was questionable (e.g., not considering effects of area size, under-sampling, and spatial non-independence).

It was challenging to address the three conjectures given above with the available studies. Many studies did not actually address them directly, even if some mentioned them to point out the relevance of agroforestry research. Furthermore, in the absence of a globally coordinated research program on data management, there is a huge variety of methods (including data analysis and its reporting), systems, spatial scales, and taxa studied. Different taxa can react very differently to the same environmental variation, jeopardizing overall conclusions $[112,170]$. The majority of studies were not experimental but compared already existing farmer-managed systems, which further weakened conclusions on causalities.

\section{Testing the Three Conjectures}

We found that many, but not a majority, of studies reported significantly higher biodiversity in agroforestry compared to agriculture, which moderately supports conjecture (1). Assumptions on the conservation benefits of agroforestry are also supported by conservation research from outside of agroforestry, which highlights the value of retaining forested secondary habitats in the tropics, in comparison to forest conversions to agricultural habitats (e.g., [171]). However, a majority of studies indicated significantly reduced diversity in agroforests compared to reference forests, so biodiversity preservation is far from complete and agroforestry cannot be viewed as a perfect substitute for forest protection. In line with this, a recent meta-analysis of biodiversity recovery after disturbance [172] indicated very long time frames for reliably restoring reference-habitat levels (see also [173, 174]).

As for conjecture (2), many studies addressed biodiversity types that were relevant to farmers and production (i.e., cultivated, volunteer, and within-system biodiversity function), but surprisingly few studies looked at how agronomic practices used by farmers within their agroforestry systems affected biodiversity. Those that did overwhelmingly focused on shade level, with most of the studies on cacao, but not in a way that would allow quantification and facilitate practical advice to farmers. This finding supports the view of Franzen and Borgerhoff Mulder (2007) [175••], who, referring to shade cacao, stated that research often targets interventions that provide benefits either to farmers or biodiversity, but not both.

Shade had positive effects on ants in Cameroonian shaded cacao [134], which may help in controlling mirid (Sahlbergella singularis) populations, and on parasitoids in Brazilian shade cacao[128], although it was not clear what these were parasitizing and whether hosts were cacao pests or not. Fungal diseases (witches' broom and blackpod), not insect pests, are generally considered the major yield constraints in South America. Other positive shade effects were on bird and plant biodiversity. Yet, the only study on cacao showing a significant biodiversity-productivity effect was from West Africa and a negative correlation was found [121]. Clearly, even so-called functional biodiversity will only show a positive impact on productivity if it is affecting a major yield constraint in the system.

Several studies suggested that landscape configuration was more important than management effects in determining biodiversity resilience, with biodiversity recovery in agroforestry systems depending on the existence of forest patches in the landscape. For example, Jakovac et al. (2015) [163], working 
in the Amazon, concluded that species diversity was more dependent on landscape configuration than on management intensity history of a fallow plot - although recovery of the structure of the forest was more dependent on the latter. However, the fallows in this study were rather young (5 years) so more and longer-term studies would be required to assess the importance of landscape configuration.

Conjecture (3), i.e., that high biodiversity in agroforest systems actually increases yields and therefore benefits farmers, was most poorly studied. This conjecture is backed by plausible ideas on ecological mechanisms, such as better nutrient cycling and lower potential for explosive population growth of pest organisms in diverse systems [176]. However, the few studies that addressed this in a tropical agroforestry context were quite equivocal (Table 3). Furthermore, results of descriptive studies on this topic are particularly susceptible to reversed causalities, as primary productivity (of which farmer's yield is a substantial part) is known to be a major determinant of biodiversity [177]. The correct assessment of the relationships between diversity and productivity or ecosystem functioning requires well-designed experimental approaches, analogous to those employed in some recent forest biodiversity experiments (for example, [178, 179]).

Thus, in conclusion, the evidence base for the three conjectures is generally not strong. There is a lack of applied, practical advice resulting from studies on conjecture (2), and proof is particularly weak on conjecture (3). More studies, with improved designs, imposed treatments, and from which the results are better documented are needed to test these conjectures with the required certainty. This is particularly relevant because they could, if proven, convince farmers and plantation owners to adopt more biodiversity-friendly management for their own utilitarian advantage (which is a stronger incentive for action than any conservation policy).

Drawing more reliable conclusions from the available literature was hampered by the multitude of approaches, combined with weak-inference study designs (i.e., mostly descriptive studies) and often unclear reporting of statistical test results. Default publishing of raw data in electronic format, as it is becoming standard in many basic science ecological journals, would facilitate future meta-analyses. There is also still a gap between the approach used in the more ecologically focused, short-term studies initiated by universities, predominantly relying on comparing existing systems, and the longer-term, more agronomic studies that are less publishable but yield more practically relevant information for farmers. Additionally, systems are undergoing rapid changes. For example, Kusters et al. (2008) [30] predicted that farmers would cut down damar agroforests in Sumatra in the near future due to external economic factors; Ekadinata and Vincent (2011) [52] have confirmed this through remote sensing data. Cacao farmers in Ghana consider traditional cacao agroforests as an archaic system, preferring lightly shaded, commercially orientated systems with newer hybrid varieties [168]. Optimizing these systems before they disappear might be achieved by a series of collaborative, multi-locational long-term trials set up in farmers' agroforestry systems. Randomly allocated types of management, as planned by the farmers, could be compared with status quo controls. Long-term data collection on yield, labor, inputs, and biodiversity would allow the relevant open questions to be addressed (e.g., link of management actions, economic benefits, and biodiversity) simultaneously.

\section{Conclusions}

Agroforestry covers a wide range of different land management systems. It was studied in different regions, with reference to different taxa, using different methods, and analyzing different responses of biodiversity. Generalized statements on research findings may therefore not be warranted. Comparisons of biodiversity to those of control habitats suggest that agroforestry has more conservation potential than agriculture but that it cannot substitute oldgrowth forests. Management practices (mostly shading regime in commodity crops) were studied either in relation to farmer's benefits or to biodiversity, but rarely both. While shade was often associated with higher biodiversity, most studies fell short of fully evaluating economic effects for farmers. Resilience, in the sense of biodiversity recovery to old-growth levels, was studied mostly in shifting cultivation systems (i.e., using fallow age as predictor). An initial review suggested recovery times of half a century, but better data are needed for reliable estimates. The distribution of old-growth habitat in the landscape (i.e., proximity of biodiversity reservoirs) emerged as an important predictor of resilience in many studies.

Acknowledgments L. Norgrove is supported by the SNSF (Swiss National Science Foundation) through a Marie Heim-Vögtlin research fellowship in Agricultural and Forestry Sciences (grant PMPDP3 145502).

\section{Compliance with Ethical Standards}

Conflict of Interest Dr. Norgrove is supported by the SNSF (Swiss National Science Foundation) through a Marie Heim-Vögtlin research fellowship in Agricultural and Forestry Sciences (grant PMPDP3_145502).

Dr. Beck declares no conflict of interest.

Human and Animal Rights and Informed Consent This article does not contain any studies with human or animal subjects performed by the author. 


\section{References}

Papers of particular interest, published recently, have been highlighted as:

- Of major importance

1. Tilman D, Reich PB, Knops J, Wedin D, Mielke T, Lehman C. Diversity and productivity in a long-term grassland experiment. Sci. 2001;294(5543):843-5.

2. Cardinale BJ, Matulich KL, Hooper DU, Byrnes JE, Duffy E, Gamfeldt L, et al. The functional role of producer diversity in ecosystems. Am J Botany. 2011;98(3):572-92.

3. Huxley PA. Comments on agroforestry classifications: with special reference to plant aspects. In: Huxley PA, editor. Plant Research and Agroforestry: proceedings of a Consultative Meeting held in Nairobi, 8 to 15 April 1981. Nairobi, Kenya: ICRAF; 1983.

4. Young A. Agroforestry for soil conservation. Nairobi, Kenya: ICRAF; 1989.

5. Nair PKR. State of the art of agroforestry. For Ecol Manag. 1991;45:5-29.

6. Sanchez PA. Science in agroforestry. Agrofor Syst. 1995;30:5-55.

7. Zomer RJ, Trabucco A, Coe R, Place F. Trees on farm: analysis of global extent and geographical patterns of agroforestry. ICRAF Working Paper - World Agroforestry Centre 2009 No. 89 pp. 63 pp.

8. Norgrove LA. Crop, weed and soil response to tree density and implications for nutrient cycling in a tropical agrisilvicultural system. UK: Doctoral dissertation, King's College London, University of London; 1999.

9. Garrity D. Agroforestry and the future of global land use. In: Nair PKR, Garrity D, editors. Agroforestry and the future of global land use. Netherlands: Springer; 2012. p. 21-7.

10. Norgrove L, Hauser S. Estimating the consequences of fire exclusion for food crop production, soil fertility and fallow recovery in shifting cultivation landscapes in the humid tropics. Environ Manag. 2015;553:536-49.

11. Guevara S, Purata SE, Van der Maarel E. The role of remnant forest trees in tropical secondary succession. Vegetatio. 1986;66(2):77-84.

12. Sirois MC, Margolis HA, Camire C. Influence of remnant trees on nutrients and fallow biomass in slash and burn agroecosystems in Guinea. Agrofor Syst. 1998;40(3):227-46.

13. Carrière SM, Letourmy P, McKey DB. Effects of remnant trees in fallows on diversity and structure of forest regrowth in a slashand-burn agricultural system in southern Cameroon. J Trop Ecol. 2002;18:375-39.

14. Diaw MC. Si, Nda Bot et Ayong : culture itinérante, occupation des sols et droits fonciers au Sud-Cameroun. Réseau foresterie pour le développement rural 21e. London: ODI; 1997.

15. Fondoun JM, Manga TT. Farmers' indigenous practices for conserving Garcinia kola and Gnetum africanum in southern Cameroon. Agrofor Syst. 2000;48(3):289-302.

16. Bailey RC, Head G, Jenike M, Owen B, Rechtman R, Zechenter E. Hunting and gathering in tropical rain forest: is it possible? Am Anthropol. 1989;91(1):59-82.

17.• Van Vliet N, Mertz O, Heinimann A, Langanke T, Pascual U, Schmook B, et al. Trends, drivers and impacts of changes in swidden cultivation in tropical forest-agriculture frontiers: a global assessment. Global Environ Change. 2012;22:418-29. A comprehensive report on the state of shifting cultivation globally.

18. Norgrove L, Hauser S. Improving plantain Musa spp. AAB yields on smallholder farms in West and Central Africa. Food Security. 2014;6(4):501-14.
19. Kang BT. Alley cropping: past achievements and future directions. Agrofor Syst. 1993;23(2-3):141-55.

20. Stamp LD. Land utilization and soil erosion in Nigeria. Geog Rev. 1938;28:32-45.

21. Metzner J. Innovations in agriculture incorporating traditional production methods: the case of Amarasi Timor. Bull Indonesian Econ Studies. 1983;193:94-105.

22. Menzies N. Three hundred years of taungya: a sustainable system of forestry in south China. Human Ecol. 1988;16:361-76.

23. Blanford HR. Highlights of one hundred years of forestry in Burma. Empire Forestry Rev. 1958;37(1):33-42.

24. Bryant RL. The rise and fall of taungya forestry. Social forestry in defence of the Empire. Ecologist. 1994;24:21-6.

25. Hansen PK, Sodarak H, Savathvong S. Teak production by shifting cultivators in Northern Lao PDR. In: Cairns M, editor. Voices from the forest:integrating indigenous knowledge into sustainable upland farming. Washington DC, USA: RFF Press; 2007. p. 414-24.

26. Van der Hout P. Effects of wider initial spacing of teak (Tectona grandis) on income and distribution in the taungya system in Java. Netherlands J Agric Sci. 1984;32:139-42.

27. Roshetko JM, Rohadi D, Perdana A, Sabastian G, Nuryartono N, Pramono AA, et al. Teak agroforestry systems for livelihood enhancement, industrial timber production, and environmental rehabilitation. Forests Trees Livelihoods. 2013;22(4):241-56.

28. Michon G, Bompard J, Hecketsweiler P, Ducatillion C. Tropical forest architectural analysis as applied to agroforests in the humid tropics: the example of traditional village agroforests in West Java. Agrofor Syst. 1983;1:117-29.

29. Torquebiau E. Man-made dipterocarp forest in Sumatra. Agrofor Syst. 1984;2:103-28.

30. Kusters K, Pérez MR, De Foresta H, Dietz T, Ros-Tonen M, Belcher B, et al. Wollenberg E Will agroforests vanish? The case of Damar agroforests in Indonesia. Human Ecol. 2008;36(3):35770 .

31. Monfreda C, Ramankutty N, Foley JA. Farming the planet: 2 . Geographic distribution of crop areas, yields, physiological types, and net primary production in the year 2000. Global Biogeochem Cycles. 2008;22:GB1022. doi:10.1029/2007GB002947.

32. Wiersum KF. Tree gardening and taungya on Java: examples of agroforestry techniques in the humid tropics. Agrofor Syst. 1983;1:53-70.

33. Spears JS. Can farming and forestry coexist in the tropics? Unasylva. 1985;32(128):2-12.

34. Christanty L. Shifting cultivation and tropical soils: patterns, problems and possible improvements. In: Marten GG, editor. Traditional agriculture in southeast Asia. Boulder, Colorado, USA: Westview Press; 1986. p. 226-40.

35. Okubo S, Tomatsu A, Muhamad D, Harashina K, Takeuchi K. Leaf functional traits and functional diversity of multistoried agroforests in West Java, Indonesia. Agric Ecosys Environ. 2012;49:91-9.

36. Smith NJH. Home gardens as a springboard for agroforestry development in Amazonia. Int Tree Crops J. 1996;9:11-30.

37. Scatena FN, Walker RT, Kingo Oyama Homma A, de Conto AJ, Palheta Ferreira CA, de Amorim Carvalho R, et al. Cropping and fallowing sequences of small farms in the 'terra firme' landscape of the Brazilian Amazon: a case study from Santarem, Pará. Ecol Econ. 1996;18:29-40

38. Carvalho TKN, Abreu DBO, de Lucena CM, Pedrosa KM, Neto CFAV, Alves CAB, et al. Structure and floristics of home gardens in an altitudinal marsh in Northeastern Brazil. Ethnobotany Res Applic. 2013;11:029-47.

39. Neulinger K, Vogl CR, Alayón-Gamboa JA. Plant species and their uses in homegardens of migrant Maya and Mestizo 
smallholder farmers in Calakmul, Campeche, Mexico. J Ethnobiol. 2013;33(1):105-24.

40. Lowe RG. Development of taungya in Nigeria. In: Gholz HG, editor. Agroforestry: realities, possibilities and potentials. Dordrecht, The Netherlands.: Martinus Nijhoff; 1987. p. 137-54.

41. Blay D, Appiah M, Damnyag L, Dwomoh FK, Luukkanen O, Pappinen A. Involving local farmers in rehabilitation of degraded tropical forests: some lessons from Ghana. Environ Dev Sustainability. 2008;104:503-18.

42. Boakye EA, Gils H, Osei EM, Asare VN. Does forest restoration using taungya foster tree species diversity? The case of Afram Headwaters Forest Reserve in Ghana. Afr J Ecol. 2012;50(3): 319-25.

43. Kalame FB, Aidoo R, Nkem J, Ajayie OC, Kanninen M, Luukkanen $\mathrm{O}$, et al. Modified taungya system in Ghana: a winwin practice for forestry and adaptation to climate change? Environ Sci Policy. 2011;14(5):519-30.

44. Watanabe H, Sahunalu P, Khemnark C. Combinations of trees and crops in the taungya method as applied in Thailand. Agrofor Syst. 1988;6:169-77.

45. Lahiri AK. Taungya-based agro-forestry trials in West Bengal. Indian Forester. 1989;115:127-32.

46. Shankar U, Lama SD, Bawa KS. Ecosystem reconstruction through 'taungya' plantations following commercial logging of a dry, mixed deciduous forest in Darjeeling Himalaya. For Ecol Manag. 1998;102:131-42.

47. Oduol PA. The shamba system: an indigenous system of food production from forest areas in Kenya. Agrofor Syst. 1986;4: 365-73.

48. Imo M. Interactions amongst trees and crops in taungya systems of western Kenya. Agrofor Syst. 2009;76(2):265-73.

49. Witcomb M, Dorward P. An assessment of the benefits and limitations of the shamba agroforestry system in Kenya and of management and policy requirements for its successful and sustainable reintroduction. Agrofor Syst. 2009;75(3):261-74.

50. Lawrence DC. Trade-offs between rubber production and maintenance of diversity: the structure of rubber gardens in West Kalimantan, Indonesia. Agrofor Syst. 1996;34:83-100.

51. Lehébel-Péron A, Feintrenie L, Levang P. Rubber agroforests' profitability, the importance of secondary products. Forests Trees Livelihoods. 2011;20(1):69-84.

52. Ekadinata A. Vincent G Rubber agroforests in a changing landscape: analysis of land use/cover trajectories in Bungo district, Indonesia. Forests Trees Livelihoods. 2011;20(1):3-14.

53. Sakchoowong W, Jaitrong W, Ogata K. Ant diversity in forest and traditional hill-tribe agricultural types in Northern Thailand. Kasetsart J Nat Sci Thailand. 2008;42(4):617-26.

54. Norgrove L, Csuzdi C, Forzi F, Canet M, Gounes J. Shifts in soil faunal community structure in shaded cacao agroforests and consequences for ecosystem function in Central Africa. Trop Ecol. 2009;50(1):71-8.

55. Cunningham RK, Arnold PW. The shade and fertiliser requirements of cacao (Theobroma cacao) in Ghana. J Sci Food Agric. 1962;13:213-21.

56. Norgrove L. Effects of different copper fungicide application rates upon earthworm activity and impacts on cocoa yield over four years. Eur J Soil Biol. 2007;43:303-10.

57. Norgrove L, Hauser S. Carbon stocks in shaded Theobroma cacao farms and adjacent secondary forests of similar age in Cameroon. Trop Ecol. 2013;54(1):15-22.

58. Santana MBM, Cabala-Rosand P. Dynamics of nitrogen in a shaded cacao plantation. Plant Soil. 1982;67:271-81.

59. Sambuichi RH, Vidal DB, Piasentin FB, Jardim JG, Viana TG, Menezes AA, et al. Cabruca agroforests in southern Bahia, Brazil: tree component, management practices and tree species conservation. Biodiv Cons. 2012;21(4):1055-77.
60. Arunguren J, Escalante G, Herrera R. Nitrogen cycle of tropical perennial crops under shade trees. 1. Coffee. Plant Soil.1982a;67: 247-258.

61. Arunguren J, Escalante G, Herrera R. Nitrogen cycle of tropical perennial crops under shade trees. 1. Cacao. Plant Soil.1982b;67: 259-269.

62. Lagemann J, Heuveldop J. Characterization and evaluation of agroforestry systems: the case of Acosta-Puriscal, Costa Rica. Agrofor Syst. 1983;1:101-15.

63. Yachi S, Loreau M. Biodiversity and ecosystem productivity in a fluctuating environment: the insurance hypothesis. Proc Nat Acad Sci. 1999;96(4):1463-8.

64. Cannell MGR, van Noordwijk M, Ong CK. The central agroforestry hypothesis: the trees must acquire resources that the crop would not otherwise acquire. Agrofor Syst. 1996;34:27-31.

65. Willey RW. Resource use in intercropping systems. Agric Water Manag. 1990;171:215-31.

66. Fukai S, Trenbath BF. Processes determining intercrop productivity and yields of component crops. Field Crop Res. 1993;34:24771.

67. Midmore DJ. Agronomic modification of resource use and intercrop productivity. Field Crop Res. 1993;34(3):357-80.

68. Rowe EC, van Noordwijk M, Suprayogo D, Hairiah K, Giller KE, Cadisch G. Root distributions partially explain $15 \mathrm{~N}$ uptake patterns in Gliricidia and Peltophorum hedgerow intercropping systems. Plant Soil. 2001;235(2):167-79.

69. Vandermeer JH. The interpretation and design of intercrop systems involving environmental modification by one of the components: a theoretical framework. Biol Agric Hort. 1984;2:135-56.

70. Charbonnier F, le Maire G, Dreyer E, Casanoves F, Christina M, Dauzat J, et al. Competition for light in heterogeneous canopies: application of MAESTRA to a coffee Coffea arabica L. agroforestry system. Agric For Meteor. 2013;181:152-69.

71. Eckstein K, Robinson JC, Fraser C. Physiological responses of banana Musa AAA/Cavendish sub-group in the subtropics. VII. Effects of windbreak shading on phenology, physiology and yield. J Hort Sci. 1997;72:389-96.

72. Norgrove, L Hauser S. Black leaf streak disease and plantain fruit characteristics as affected by tree density and biomass management in a tropical agroforestry system. Agrofor. Syst. 2013b;87(2):349-354.

73. Buresh RJ, Tian G. Soil improvement by trees in sub-Saharan Africa. Agrofor Syst. 1998;38:51-76.

74. Belsky AJ. Influences of trees on savanna productivity: tests of shade, nutrients, and tree-grass competition. Ecol. 1994;75(4): 922-32.

75. Ofori-Bah A, Asafu-Adjaye J. Scope economies and technical efficiency of cocoa agroforestry systems in Ghana. Ecol Econ. 2011;70(8):1508-18.

76. Blackman A, Ávalos-Sartorio B, Chow J. Land cover change in agroforestry: shade coffee in El Salvador. Land Econ. 2012;88(1): 75-101.

77. Mead R, Willey RW. The concept of a 'land equivalent ratio' and advantages in yields from intercropping. Exper Agric. 1980;16: $217-28$.

78. Leakey RRB. The role of trees in agroecology and sustainable agriculture in the tropics. Ann Rev Phytopath. 2014;52:113-33.

79. Nelder JA. New kinds of systematic designs for spacing experiments. Biometrics. 1962;18:283-307.

80. Marquard E, Weigelt A, Temperton VM, Roscher C, Schumacher J, Buchmann N, et al. Plant species richness and functional composition drive overyielding in a six-year grassland experiment. Ecol. 2009;90(12):3290-302.

81. Schultz B, Phillips C, Rosset P, Vandermeer J. An experiment in intercropping cucumbers and tomatoes in southern Michigan. USA Sci Hort. 1982;18(1):1-8. 
82. Snelder DJ, Klein M, Schuren SHG. Farmers' preferences, uncertainties and opportunities in fruit-tree cultivation in Northeast Luzon. Agrofor Syst. 2007;71(1):1-17.

83. Mekonnen A. Tenure security, resource endowments, and tree growing: evidence from the Amhara region of Ethiopia. Land Econ. 2009;85(2):292-307.

84. Fenske J. Land tenure and investment incentives: evidence from West Africa. J Dev Econ. 2011;95(2):137-56.

85. Ramírez OA, Somarriba E, Ludewigs T, Ferreira P. Financial returns, stability and risk of cacao-plantain-timber agroforestry systems in Central America. Agrofor Syst. 2011;51(2):141-54.

86. Bhagwat SA, Willis KJ, Birks HJB, Whittaker RJ. Agroforestry: a refuge for tropical biodiversity? Trends Ecol Evol. 2008;23(5): 261-7.

87. Scales BR, Marsden SJ. Biodiversity in small-scale tropical agroforests: a review of species richness and abundance shifts and the factors influencing them. Environ Cons. 2008;35(02): 160-72.

88. Hartemink AE. Assessing soil fertility decline in the tropics using soil chemical data. Adv Agron. 2006;89:179-225.

89. Pickett ST. Space-for-time substitution as an alternative to longterm studies. In: Likens GE, editor. Long-term studies in ecology. New York: Springer; 1989. p. 110-35.

90.• Lebrija-Trejos E, Bongers F, Pérez-García EA, Meave JA. Successional change and resilience of a very dry tropical deciduous forest following shifting agriculture. Biotropica. 2008;40(4): 422-31. A comprehensive case study on resilience in shifting cultivation using many age classes representing the succession of very dry tropical deciduous forest in Mexico.

91. Norgrove L, Hauser S. Biophysical criteria used by farmers for fallow selection in West and Central Africa. Ecol Indic. doi:10. 1016/j.ecolind.2015.06.013. in press.

92. Holling CS. Resilience and stability of ecosystems. Ann Rev Ecol Syst. 1973;4:1-23.

93. Scheffer M, Carpenter S, Foley JA, Folke C, Walker B. Catastrophic shifts in ecosystems. Nature. 2001;413(6856):5916.

94. Tittonell P. Livelihood strategies, resilience and transformability in African agroecosystems. Agric Syst. 2014;126:3-14.

95. Trenbath BR. Weeds and agriculture: a question of balance. In: White J, editor. Studies on plant demography. A festschrift for John L Harper. London: Academic Press; 1985. p. 171-83.

96. Szott LT, Palm CA, Buresh RJ. Ecosystem fertility and fallow function in the humid and subhumid tropics. Agrofor Syst. 1999;47(1-3):163-96.

97. Albers HJ, Goldbach MJ. Irreversible ecosystem change, species competition, and shifting cultivation. Res Energy Econ. 2000;22(3):261-80.

98. Biala K, Peeters A, Muys B, Hermy M, Brouckaert V, García V, et al. Biodiversity indicators as a tool to assess sustainability levels of agro-ecosystems, with a special consideration of grassland areas. In: Molina AE, Ben Salem H, Biala K, Morand-Fehr P, editors. Sustainable grazing, nutritional utilization and quality of sheep and goat products Zaragoza: CIHEAM, 2005 p 439-443 (Options Méditerranéennes: Série A Séminaires Méditerranéens; n 67).

99. Beukema H, Danielsen F, Vincent G, Hardiwinoto S, Van Andel J. Plant and bird diversity in rubber agroforests in the lowlands of Sumatra. Indonesia Agrofor Syst. 2007;70(3):217-42.

100. Kishimoto-Yamada K, Itioka T, Nakagawa M, Momose K, Nakashizuka T. Phytophagous scarabaeid diversity in swidden cultivation landscapes in Sarawak, Malaysia. Raffles Bull Zool. 2011;59(2):285-93.

101. Holbech LH. The conservation importance of luxuriant tree plantations for lower storey forest birds in south-west Ghana. Bird Conservation Int. 2009;19(03):287-308.
102. Gao L, Liu HM. Rotation system for Cardamom planting and forest regeneration in the tropical rainforest of southwest China. J Trop For Sci. 2009;21(3):190-7.

103. Mo XX, Zhu H, Zhang YJ, Slik JF, Liu JX. Traditional forest management has limited impact on plant diversity and composition in a tropical seasonal rainforest in SW China. Biol Cons. 2011;144(6):1832-40.

104. Arias RM, Heredia-Abarca G, Sosa VJ, Fuentes-Ramírez LE. Diversity and abundance of arbuscular mycorrhizal fungi spores under different coffee production systems and in a tropical montane cloud forest patch in Veracruz. Mexico Agrofor Syst. 2012;85(1):179-93.

105. Bobo KS, Waltert M, Fermon H, Njokagbor J, Mühlenberg M. From forest to farmland: butterfly diversity and habitat associations along a gradient of forest conversion in Southwestern Cameroon. J Insect Cons. 2006;10(1):29-42.

106. Bobo KS, Waltert M, Sainge NM, Njokagbor J, Fermon H, Mühlenberg M. From forest to farmland: species richness patterns of trees and understorey plants along a gradient of forest conversion in Southwestern Cameroon. Biodiv Cons. 2006;15(13): 4097-117.

107. Braga RF, Korasaki V, Audino LD, Louzada J. Are dung beetles driving dung-fly abundance in traditional agricultural areas in the Amazon? Ecosyst. 2012;15(7):1173-81.

108. Eggleton P, Bignell DE, Hauser S, Dibog L, Norgrove L, Madong B. Termite diversity across an anthropogenic disturbance gradient in the humid forest zone of West Africa. Agric Ecosys Environ. 2002;90(2):189-202.

109. Harvey CA, Villalobos JAG. Agroforestry systems conserve species-rich but modified assemblages of tropical birds and bats. Biodiv Cons. 2007;16(8):2257-92.

110. Laliberté E, Tylianakis JM. Deforestation homogenizes tropical parasitoid-host networks. Ecol. 2010;91(6):1740-7.

111.• Rousseau L, Fonte SJ, Téllez O, Van der Hoek R, Lavelle P. Soil macrofauna as indicators of soil quality and land use impacts in smallholder agroecosystems of western Nicaragua. Ecol Indic. 2013;27:71-82. A case study focussing on the role of soil faunal functional biodiversity in multistrata systems with both forest and agricultural controls.

112. Schulze CH, Waltert M, Kessler PJA, Pitopang R, Shahabuddin, Veddeler D, et al. Biodiversity indicator groups of tropical landuse systems: comparing plants, birds, and insects. Ecol Appl. 2004;14(5):1321-1333.

113. Schulze $\mathrm{CH}$, Tscharntke T. Changes of dung beetle communities from rainforests towards agroforestry systems and annual cultures in Sulawesi (Indonesia). Biodiv Cons. 2005;14(4):863-77.

114. Steffan-Dewenter I, Tscharntke T. Biodiversity indicator groups of tropical land-use systems: comparing plants, birds, and insects. Ecol Appl. 2004;14(5):1321-33.

115. Teodoro AV, Muñoz A, Tscharntke T, Klein AM, Tylianakis JM. Early succession arthropod community changes on experimental passion fruit plant patches along a land-use gradient in Ecuador. Agric Ecosys Environ. 2011;140:14-9.

116. Waltert M, Mardiastuti A, Mühlenberg M. Effects of land use on bird species richness in Sulawesi. Indonesia Cons Biol. 2004;18(5):1339-46.

117. Waltert M, Bobo KS, Sainge NM, Fermon H, Mühlenberg M. From forest to farmland: habitat effects on Afrotropical forest bird diversity. Ecol Appl. 2005;15(4):1351-66.

118. Waltert M, Bobo KS, Kaupa S, Montoya ML, Nsanyi MS, Fermon $\mathrm{H}$. Assessing conservation values: biodiversity and endemicity in tropical land use systems. PLoS One. 2011;6(1):e16238.

119. Bieng MAN, Gidoin C, Avelino J, Cilas C, Deheuvels O, Wery J. Diversity and spatial clustering of shade trees affect cacao yield and pathogen pressure in Costa Rican agroforests. Basic Appl Ecol. 2013;14(4):329-36. 
120. Kessler M, Hertel D, Jungkunst HF, Kluge J, Abrahamczyk S, Bos $\mathrm{M}$, et al. Can joint carbon and biodiversity management in tropical agroforestry landscapes be optimized? PLoS One. 2012;7(10):10. 1371/journal.pone.0047192.

121. Wade AS, Asase A, Hadley P, Mason J, Ofori-Frimpong K, Preece $\mathrm{D}$, et al. Management strategies for maximizing carbon storage and tree species diversity in cocoa-growing landscapes. Agric Ecosys Environ. 2010;138(3):324-34.

122. Saha SK, Nair PR, Nair VD, Kumar BM. Soil carbon stock in relation to plant diversity of homegardens in Kerala. India Agrofor Syst. 2009;76(1):53-65.

123. Méndez VE, Gliessman SR, Gilbert GS. Cooperative management and its effects on shade tree diversity, soil properties and ecosystem services of coffee plantations in western El Salvador. Agrofor Syst. 2009;76(1):111-26.

124. Haggar JP, Ewel JJ. Primary productivity and resource partitioning in model tropical ecosystems. Ecol. 1997;78(4):1211-21.

125. Waldron A, Justicia R, Smith L, Sanchez M. Conservation through chocolate: a win-win for biodiversity and farmers in Ecuador's lowland tropics. Cons Letters. 2012;5(3):21321.

126. Kessler M, Abrahamczyk S, Buchori D, Putra DD, Gradstein SR, Hohn P, et al. Alpha and beta diversity of plants and animals along a tropical land-use gradient. Ecol Appl. 2009;19(8):2142-56.

127. Wanger TC, Iskandar DT, Motzke I, Brook BW, Sodhi NS, Clough Y, et al. Effects of land-use change on community composition of tropical amphibians and reptiles in Sulawesi. Indonesia Cons Biol. 2010;24(3):795-802.

128. Sperber CF, Nakayama K, Valverde MJ, de Siqueira Neves F. Tree species richness and density affect parasitoid diversity in cacao agroforestry. Basic Appl Ecol. 2004;5(3):241-51.

129. Hoehn P, Steffan-Dewenter I, Tscharntke T. Relative contribution of agroforestry, rainforest and openland to local and regional bee diversity. Biodiv Cons. 2010;19(8):2189-200.

130. Shahabuddin, Hidayat P, Manuwoto S, Noerdjito WA, Tscharntke T, Schulze CH. Diversity and body size of dung beetles attracted to different dung types along a tropical land-use gradient in Sulawesi, Indonesia. J Trop Ecol. 2010;26(01):53-65.

131. Bos MM, Tylianakis JM, Steffan-Dewenter I, Tscharntke T. The invasive yellow crazy ant and the decline of forest ant diversity in Indonesian cacao agroforests. Biol Invasions. 2008;10(8):1399 409

132. Rizali A, Clough Y, Buchori D, Hosang ML, Bos MM, Tscharntke T. Long-term change of ant community structure in cacao agroforestry landscapes in Indonesia. Insect Cons Divers. 2013;6(3):32838.

133. Bos MM, Steffan-Dewenter I, Tscharntke T. The contribution of cacao agroforests to the conservation of lower canopy ant and beetle diversity in Indonesia. Biodiv Cons. 2007;16(8):2429-44.

134. Bisseleua HBD, Fotio D, Missoup AD, Vidal S. Shade tree diversity, cocoa pest damage, yield compensating inputs and farmers' net returns in West Africa. PLoS One. 2013;8(3):e56115. doi:10. 1371/journal.pone.0056115.

135. Sporn SG, Bos MM, Hoffstätter-Müncheberg M, Kessler M, Gradstein SR. Microclimate determines community composition but not richness of epiphytic understory bryophytes of rainforest and cacao agroforests in Indonesia. Funct Plant Biol. 2009;36(2): $171-9$.

136. Cicuzza D, Clough Y, Tjitrosoedirdjo SS, Kessler M. Responses of terrestrial herb assemblages to weeding and fertilization in cacao agroforests in Indonesia. Agrofor Syst. 2012;85(1):75-83.

137. Klein A-M, Steffan-Dewenter I, Tscharntke T. Rain forest promotes trophic interactions and diversity of trap-nesting Hymenoptera in adjacent agroforestry. J Animal Ecol. 2006;75(2):315-23.
138. Teodoro AV, Sousa-Souto L, Klein AM, Tscharntke T. Seasonal contrasts in the response of coffee ants to agroforestry shade-tree management. Environ Entom. 2010;39(6):1744-50.

139. Williams-Guillén K, Perfecto I. Effects of agricultural intensification on the assemblage of leaf-nosed bats (Phyllostomidae) in a coffee landscape in Chiapas. Mexico Biotropica. 2010;42(5):605-13.

140. Méndez VE, Gliessman SR, Gilbert GS. Tree biodiversity in farmer cooperatives of a shade coffee landscape in western El Salvador. Agric Ecosys Environ. 2007;119(1):145-59.

141. García-Fernández C, Casado MA. Forest recovery in managed agroforestry systems: the case of benzoin and rattan gardens in Indonesia. For Ecol Manag. 2005;214(1):158-69.

142. Lozada T, De Koning GHJ, Marché R, Klein AM, Tscharntke T. Tree recovery and seed dispersal by birds: comparing forest, agroforestry and abandoned agroforestry in coastal Ecuador. Perspect Plant Ecol Evol Syst. 2007;8(3):131-40.

143. Castro-Luna AA, Sosa VJ, Castillo-Campos G. Bat diversity and abundance associated with the degree of secondary succession in a tropical forest mosaic in south-eastern Mexico. Animal Cons. 2007;10(2):219-28.

144. Pawar SS, Rawat GS, Choudhury BC. Recovery of frog and lizard communities following primary habitat alteration in Mizoram. Northeast India BMC Ecol. 2004;4(1):10. doi:10.1186/14726785-4-10.

145. Nakagawa M, Miguchi H, Nakashizuka T. The effects of various forest uses on small mammal communities in Sarawak, Malaysia. Forest Ecol Manage. 2006;231(1):55-62.

146. Shankar Raman TR, Rawat GS, Johnsingh AJT. Recovery of tropical rainforest avifauna in relation to vegetation succession following shifting cultivation in Mizoram, north-east India. J Appl Ecol. 1998;35(2):214-31.

147. $\mathrm{Bu} \mathrm{W}$, Zang R, Ding Y. Field observed relationships between biodiversity and ecosystem functioning during secondary succession in a tropical lowland rainforest. Acta Oecol. 2014;55:1-7.

148. Itioka T, Takano KT, Kishimoto-Yamada K, Tzuchiya T, Ohshima Y, Katsuyama RI, et al. Chronosequential changes in species richness of forest-edge-dwelling butterflies during forest restoration after swidden cultivation in a humid tropical rainforest region in Borneo. J For Res. 2015;20(1):125-34.

149. Nakagawa M, Momose K, Kishimoto-Yamada K, Kamoi T, Tanaka HO, Kaga M, et al. Tree community structure, dynamics, and diversity partitioning in a Bornean tropical forested landscape. Biodiv Cons. 2013;22(1):127-40.

150. Piotto D, Montagnini F, Thomas W, Ashton M, Oliver C. Forest recovery after swidden cultivation across a 40 -year chronosequence in the Atlantic forest of southern Bahia. Brazil Plant Ecol. 2009;205(2):261-72.

151. Fujisaka S, Escobar G, Veneklaas E. Plant community diversity relative to human land uses in an Amazon forest colony. Biodiv Cons. 1998;7(1):41-57.

152. Wangpakapattanawong P, Kavinchan N, Vaidhayakarn C, Schmidt-Vogt D, Elliott S. Fallow to forest: applying indigenous and scientific knowledge of swidden cultivation to tropical forest restoration. Forest Ecol Manage. 2010;260(8):1399-406.

153. Kennard DK. Secondary forest succession in a tropical dry forest: patterns of development across a 50-year chronosequence in lowland Bolivia. J Trop Ecol. 2002;18(01):53-66.

154. Tanaka HO, Yamane S, Nakashizuka T, Momose K, Itioka T. Effects of deforestation on mutualistic interactions of ants with plants and hemipterans in tropical rainforest of Borneo. Asian Myrmecol. 2007;1:31-50.

155. Williams M, Ryan CM, Rees RM, Sambane E, Fernando J, Grace J. Carbon sequestration and biodiversity of re-growing miombo woodlands in Mozambique. Forest Ecol Manage. 2008;254(2): $145-55$. 
156. Klanderud K, Mbolatiana HZH, Vololomboahangy MN, Radimbison MA, Roger E, Totland Ø, et al. Recovery of plant species richness and composition after slash-and-burn agriculture in a tropical rainforest in Madagascar. Biodiv Cons. 2010;19(1): 187-204.

157. Toledo M, Salick J. Secondary succession and indigenous management in semideciduous forest fallows of the Amazon Basin. Biotropica. 2006;38(2):161-70.

158.• De Wilde M, Buisson E, Ratovoson F, Randrianaivo R, Carrière SM, Lowry II PP. Vegetation dynamics in a corridor between protected areas after slash-and-burn cultivation in south-eastern Madagascar. Agric Ecosyst Environ. 2012;159:1-8. A case study with sufficient age categories to demonstrate fallow succession in shifting cultivation as well as assessing the impacts of different cultivation practices on fallow succession.

159. N'Dja JK, Decocq G. Régénération de la forêt dense semi-décidue dans les stades post - culturaux en forêt classée de Sanaimbo (Côte-d'Ivoire). Acta Botanica Gallica. 2007;154(3):395-405.

160. McNamara S, Erskine PD, Lamb D, Chantalangsy L, Boyle S. Primary tree species diversity in secondary fallow forests of Laos. Forest Ecol Manag. 2012;28(1):93-9.

161. Kupfer JA, Webbeking AL, Franklin SB. Forest fragmentation affects early successional patterns on shifting cultivation fields near Indian Church. Belize Agric Ecosys Environ. 2004;103(3): 509-18.

162. Randriamalala JR, Hervé D, Randriamboavonjy JC, Carrière SM. Effects of tillage regime, cropping duration and fallow age on diversity and structure of secondary vegetation in Madagascar. Agric Ecosys Environ. 2012;155:182-93.

163. Jakovac CC, Peña-Claros M, Kuyper TW, Bongers F. Loss of secondary-forest resilience by land-use intensification in the Amazon. J Ecol. 2015;103(1):67-77.

164. Randriamalala JR, Hervé D, Letourmy P, Carrière SM. Effects of slash-and-burn practices on soil seed banks in secondary forest successions in Madagascar. Agric Ecosys Environ. 2015;199:312-9.

165. Green RE, Cornell SJ, Scharlemann JPW, Balmford A. Farming and the fate of wild nature. Science. 2005;307:550-5.

166. Phalan B, Green R, Balmford A. Closing yield gaps: perils and possibilities for biodiversity conservation. Phil Trans R Soc BBiol Sci. 2014;369.
167. Ioannidis JPA. Why most published research findings are false. PLoS Med. 2005;2:e124.

168. Ruf FO. The myth of complex cocoa agroforests: the case of Ghana. Human Ecol. 2011;39(3):373-88.

169. Gurevitch J. Curtis, P S, Jones, M H. Meta-analysis in ecology Adv Ecol Res. 2001;32:199-247.

170. Beck J, Pfiffner L, Ballesteros-Mejia L, Blick T, Luka H. Revisiting the indicator problem: can three epigean arthropod taxa inform about each other's biodiversity? Diversity Distribut. 2013;19:688-99.

171. Newbold T, Hudson LN, Hill SLL, Contu S, Lysenko I, Senior RA, et al. Global effects of land use on local terrestrial biodiversity. Nature. 2015;520(7545):45-50.

172. Curran M, Hellweg S, Beck J. Is there any empirical support for biodiversity offset policy? Ecol Applic. 2014;24:617-32.

173. Quetier F, Van Teeffelen AJA, Pilgrim JD, von Hase A, ten Kate K. Biodiversity offsets are one solution to widespread poorlycompensated biodiversity loss - a response to Curran et al. Ecol Applic. 2015;25(6):1739-41.

174. Curran M, Hellweg S, Beck J. The jury is still out on biodiversity offsets-Reply to Quétier et al. Ecol Applic. 2015;25:1741-6.

175.• Franzen M, Borgerhoff Mulder M. Ecological, economic and social perspectives on cocoa production worldwide. Biodiv Conserv. 2007;16:3835-49. This paper provides a critical view on biodiversity research in cacao systems and suggests practical ways to minimize trade-offs between production and conservation.

176. Kricher J. Tropical ecology. Princeton, N.J: Princeton University Press; 2011.

177. Storch D, Marquet PA, Brown JH. Scaling biodiversity. Cambridge: Cambridge University Press; 2007.

178. Bruelheide H, Nadrowski K, Assmann T, Bauhus J, Both S, Buscot F, et al. Designing forest biodiversity experiments: general considerations illustrated by a new large experiment in subtropical China. Meth Ecol Evol. 2014;5:74-89.

179. Verheyen K, Vanhellemont M, Auge H, Baeten L, Baraloto C, Barsoum N, et al. Contributions of a global network of tree diversity experiments to sustainable forest plantations. Ambio. DOI 10. 1007/s13280-015-0685-1. In press. 